\title{
IMPLEMENTATION OF NON-COMPETITION CLAUSE AS THE BASIS OF TRADE SECRET PROTECTION IN INDONESIA
}

\author{
Sartika Nanda Lestari, Sakhiyatu Sova and Rinitami Njatrijani \\ Law Faculty of Universitas Diponegoro Semarang, Indonesia \\ E-mail: sartikananda@live.undip.ac.id
}

\begin{abstract}
Each company has trade strategies that should not be known by other parties; therefore, Trade Secret is necessary to protect them. Trade secret emerges from an agreement between employees and company, one of which is by implementing Non-Competition Clause in that agreement. This article accordingly discusses about how the implementation of Non-Competition Clause and the legal consequence of the implementation of Non-Competition Clause as the form of trade secret protection. Regarding the issue discussed in this paper, the result shows that the implementation of NonCompetition Clause in employment agreement must be conducted based on Trade Secret Law which causes legal consequence like employees prohibitions as an effort to keep their commercial in confidence. However, the implementation of Non-Competition Clause has not been effectively implemented for there is no detailed explanation in the agreement resulting in the different clause interpretation between company and employees. Therefore, it is necessary to have separated and detailed regulation concerning Non-Competition Clause in the employment agreement.
\end{abstract}

Keywords: non-competition clause, employment agreement, trade secret

Abstrak

Setiap perusahaan dalam melaksanakan proses perdagangan memiliki strategi dagang masing-masing yang tidak boleh diketahui oleh pihak lain, karenanya diperlukan Rahasia Dagang untuk melindungi strategi tersebut. Rahasia dagang dapat lahir dari perjanjian kerja antara pekerja dan perusahaan, salah satunya adalah dengan menerapkan Non-Competition Clause dalam perjanjian kerja. Artikel ini membahas lebih lanjut mengenai bagaimana penerapan Non-Competition Clause serta akibat hukum Non-Competition Clause sebagai bentuk perlindungan rahasia dagang. Berdasarkan masalah yang diangkat dalam tulisan ini, ditemukan bahwa penerapan Non-Competition Clause dalam perjanjian kerja wajib dilakukan berdasarkan Undang-Undang Rahasia Dagang yang menimbulkan akibat hukum adanya larangan-larangan bagi pekerja sebagai upaya untuk menjaga rahasia dagang perusahaan. Namun, penerapan Non-Competition Clause belum maksimal karena dalam perjanjian kerja belum dijelaskan secara terperinci yang mengakibatkan perbedaan dalam memahami maksud klausula tersebut antara perusahaan dan karyawan. Sehingga perlu adanya pengaturan tersendiri dan rinci mengenai Non-Com-petition Clause dalam perjanjian kerja.

Kata kunci: non-competition clause, perjanjian kerja, rahasia dagang

Introduction

Persistently rapid and significant economic development encourages companies to continuously develop their business and technology for high competitiveness. Many companies in Indonesia are ready to spend considerable budget to support their business development. Beside attempting to give the best result and maximizing the fulfillment of consumers' rights, strategy, method and technology become the significant factors to maintain the company ex- istence. ${ }^{1}$ Certainly, those factors are not necessarily publicly recognized especially competitors. This kind of information is important for the improvement and the benefit of company for its high economic value. Due to its confidentiality, the company applies trade secret as an ideal protection for its business. This protection is chosen for two reasons. First, the protected

Robert N. Mayer, "Protectionism, Intellectual Property, and Consumer Protection", Journal Consumer Protection, Vol. 21 No. 2, June 1998, p. 196. 
substance is something that cannot be given the patent such as list of consumers, financial data, business notes, etc. Second, the protected substance is possibly to be given the patent but the investors prefer choosing Trade Secret protection since there are no time limit, the secret value is more secured, the patent is more expensive and the registration process of patent is more complicated.

The economic analysis of trade secret protection is based on business plan, business management, process and procedure of production which are secured from public in the fields of technology and/or business. They have economic value since it is useful for business activities and the confidentiality is protected. ${ }^{2}$ Trade secret is intelectual property that is sensitive, abstract, and closed for its deliberately concealed information. ${ }^{3}$

The trade secret may be established from relations one of which is work relation. Any legal relation has own legal consequence of the trade secret disclosure itself. It is important to maintain the protection to secure the valuable information.

The basic concept to protect the trade secret is ensuring the investors to develop ideas and information or any commercial value concept for the investment by obtaining the exclusive right to use the secret or to prevent other parties from using it illegally which causes monopoly right. ${ }^{4}$ Hence, in trade secret, it is obligetory to secure the commercial in confidence. Keeping the trade secret requires legal relation among workers in which work is the main element of working relation that causes workers' obligation to protect the commercial in confidence. ${ }^{5}$

2 David D. Friedman, William M. Landes, Richard A. Posner, "Some Economic of Trade Secret Law", The Journal of Economic Perspectives, Vol. 5 No. 1, Winter 1991, p. 61.

3 Stefan Bechtold and Felix Hoffler, "An Economic Analysis of Trade-Secret Protection in Buyer-Seller Relationships", The Journal of Law, Economics, and Organization, Vol. 27 No. 1, April 2011, p. 137.

4 Youngmin Chen, "Refusal to Deal, Intellectual Property Rights, and Antitrust", The Journal of Law, Economics, and Organization, Vol. 30 No. 3, August 2014, p. 533.

5 Amalia, Rizki, "Non Competition Clause Dalam Perjanjian Kerja", Yuridika, Vol. 26 No. 2, 26 May 2011, p. 117.
The employment agreement is formulated to manage the rights and obligations of the parties as well as the trade secret. Thus, the employment agreement between employer and the workers aims to protect the corporate secret. In his regard, there is freedom of contract principle in which the parties are free to formulate the content of the agreement. ${ }^{6}$ Each employment agreement may be made in form of written or spoken. If it is written, it must be based on applicable legislations. It requires parties' agreement, legal action capability, the contracted job, and the contracted job is not contradicted with public order, morality and applicable legislations.

Article 52 section (1) letter a Law Number 13 Year 2003 on Employment states that there is agreement of both parties which enables them to arrange employment agreement mentioning that trade secret will remain secured although the agreement expired. In many legislations of labor, no regulation prohibits an agreement to keep corporate secret. Thus, it is in line with the legislations and can be applied by the employees to protect the worthy information.

The corporate's effort to protect the trade secret is implemented by adding NonCompe-tition Clause in their employment agreement. Generally, $70.2 \%$ of companies require the top executives to sign the employment agreement to which NonCompetition Clause is added ${ }^{7}$.

Non-competition Clause regulates that the employees agree to be engaged to the corporate and will not work in the same or different position in competitor's corporate, or build a business in the same field in particular period of time after the date of employment termination $^{8}$.

Ghansam Anand, "Prinsip Kebebasan Berkontrak dalam Penyusunan Kontrak", Yuridika, Vol. 26 No.2, 26 May 2011, p. 91.

7 Mark Garmaise, “Ties That Truly Blind: Non-Competition Agreements, Executive Compensation, and Firm Investment", Journal of Law, Economics, and Organization, Vol. 27, 2011, p. 376.

8 Matt Marx, "The Firm Strikes back: Non-Compete Agreements and the Mobility of Technical Professionals", 
Implementations of Non-Competition Clause include employment agreement and statement letter. The implementation of Non-Competition Clause in employment agreement is mostly found without certain period. Meanwhile, in statement letter, it is usually given by the employer to the employees in an agreement without Non-Competition Clause. Till now, there is no legislation which specifically forbids or allows the use of Non-Competition Clause in Indonesia.

Law in Indonesia does not strictly forbid or allow Non-Competition Clause to be attached in employment agreement. Based on the 1945 Constitution, Law of Employment, and Law of Human Rights, this clause cannot be implemented in employment agreement in Indonesia because principally this clause is contradicted. However, from the perspective of employer, without this clause, there is an anxiety if the employees will reveal the secret or give their precious information to the competitors.

It undoubtedly raises the confusion of legal certainty on the implementation of NonCompetition Clause as the basis of trade secret protection in Indonesia. Therefore, this paper will analyze the implementation of Non-Competition Clause and its legal consequence in Indonesia as an effort of trade secret protection.

\section{Discussion}

\section{Theory of Trade Secret Protection}

Trade Secret is intangible asset and has several theories in its protection. The protection of Trade Secret is based on the theories below. ${ }^{9}$ First, the theory of ownership right is one of the theories regarding Trade Secret protec-tion because Trade Secret is one of assets. Based on economic analysis, Trade Secret contains crucial business information and considered as corporate's investment. ${ }^{10}$ It can be aligned as a form of ownership right even it is

American Sociological Review, Vol. 76 No. 5, August 2011, p. 698.

9 Sudjana and Elisantris Gultom, 2016, Rahasia Dagang dalam Perspektif Perlindungan Konsumen, Bandung: CV Keni Media, p. 67.

10 Mark F. Schultz, "Approaches to Protection of Undisclosed Information (Trade Secrets)", OECD Trade Policy, Vol. 16 No. 1, April 2014, p. 11 identical with individual or corporate asset or investment. As ownership right, Trade Secret is exclusive and can be protected from anyone attempting to abuse or take benefit without proper right. The owner has the right to use it broadly as long as it does not break the law.

Second, contract theory is the basis mostly presented in the trial process of Trade Secret. In Indonesian legal system which adopts Continental European legal principle, the contract or agreement is generally an engagement source (Article 1233 Burgerlijk wetboek/ Code of Civil Law) and in line with 1338 Burgerlijk wetboek stating that the legally formulated agreement is applied as the law. Thus, the agreement cannot be cancelled only by one party and the violation considers as breach. ${ }^{11}$ The protection principle based on this contract is relevant with the protection based on the employment legal system. The relation between the employer and the employees is one of important factors in Trade Secret. The high number of the moving employees from one corporate to another causes the need of integrating the Trade Secret regulation into the Employment Law. ${ }^{12}$

Third, unlawful act theory, the protection of Trade Secret can also be conducted based on unlawful act theory. It is one of solutions as the consequence of the protection of unregisterred intelectual property like Trade Secret. This principle is mostly applied in many countries to solve unfair competition conducted by competitors who have bad intention. ${ }^{13}$

Implementation of Non-Competition Clause as the Basis of Trade Secret Protection in Indonesia

According to Phillip Griffith, in Sudjana and E. Gultom's book entitled Rahasia Dagang dalam Perspektif Perlindungan Konsumen, Trade Secret protection is generally divided into two types. ${ }^{14}$ First, common law approach is used by the state implicating the Common Law

1 Sudjana and Elisantris Gultom, Op.Cit., p. 67.

12 Ahmad M. Ramli, 2000, H.A.K.I: Teori Dasar Perlindungan Rahasia Dagang, Bandung: Mandar Maju, p. 50-52.

13 Sudjana and Elisantris Gultom, Op.Cit., p. 67.

14 Ibid., p. 68. 
system, like United Kingdom. The Trade Secret protec-tion in U.K. is regulated in the Law of Confidence since 1800. Common Law system does not limit the types of information which can be cat-egorized as Trade Secret. They can be business information, personal information, governmen-tal information and any other information. Meanwhile, information owned by certain party is not considered as a property, rather, it is more likely a relation which one of the parties obliged to keep the information due to the relation (confidential relationship) and this information is considered intangible. If that party reveals the confidential information either consiously or unconsiously, this action will be considered as breach of confidential or breach of fiduciary obligatoir or breach of contract which is a violation of Trade Secret and it causes loss to the owner. ${ }^{15}$

Second, statutory approach. It is commonly used by the states with Civil Law sytem including Indonesia. As other Civil Law states, Netherland does not have specific provision on Trade Secret. If violation of Trade Secret occurs, it is viewed as "unlawful act". The first case in jurisprudence was the case of Lindenbaum versus Cohen (Verdict of Hoge Raad Nederland January 31, 1919). ${ }^{16}$ It became popular since it showed that Article $1365 \mathrm{BW}$ regulating unlawful act had accomodatively protected forms of Trade Secret known as customer list, marketing method, and financial data (price) of a company. ${ }^{17}$

Trade Secret protection principles used in Statutory Approach are unlawful act principle, contract principle, good intention principle, and criminal penalty conditions. The substance of protected information is used in trading or business information and will be secured by the corporate. It means that this is not necessarily human work or intellectual property, for instance, the increase or decrease of market share. ${ }^{18}$

Indonesian law system adheres to Civil Law legal system (Continental Europe) because

\footnotetext{
5 Ibid.

16 Ahmad M. Ramli, op.cit., p. 51-52.

17 Sudjana dan Elisantris Gultom, op.cit., p. 71

18 Ibid, p. 72
}

Indonesia was the former of Netherland's colony which used to apply Civil Law system. This system was adopted from French Civil Law system. This system was developed through the scientists's doctrines influenced by Natural Law, which is human artificial law or legislations. ${ }^{19}$ Therefore, the form of Trade Secret protection in Indonesia is Statutory Approach. Legislation that regulates Trade Secret is Law Number 30 Year 2000 on Trade Secret. Statutory Approach is based on a legislation which allows the existence of employment agreement.

In Indonesia, the form of trade secret protection can be classified into preventive form and repressive form (the act that is taken after getting legal consequence). ${ }^{20}$ Preventive protection is in form of contract or agreement which aims to realize legal certainty and justice either for the parties who make the agreement or the third parties. Consequently, an agreement or contract must be made in accordance with applicable law. Moreover, repressive protection is in form of written admonition in a contract which is signed by all parties emphasizing that if the employees break their agreement, it does not immediately break their cooperation contract. Yet, they will be given written admonition three times in a row and if they still do not pay attention, the company will do employment termination or file lawsuit.

The addition of certain clauses is possible in employment agreement, one of which is NonCompetition Clause. It is in accordance with Article 3 section (1) of Law Number 30 Year 2000 on Trade Secret stating "Trade Secret is protected if the information is confidential, has economic value, and it is kept through necessary effort". The meaning of "necessary effort" is all steps that contain naturalness and appropriateness which have to be done. For example, in internal regulation of the company, it can be determined how Trade Secret is protected and

\footnotetext{
19 Kai Purhagen, "Principles of European Private or Civil Law?", European Law Journal, Vol. 18 No. 16, November 2012, p. 844.

20 Maxim V. Tsotsorin, "Practical Considerations in Trade Secret Licensing", Intellectual Property Patent Law Journal, Vol. 10 No. 3, October 2012, p. 202.
} 
who takes the responsibility of its confidentiality.

The trade secret protection must be made to make other parties like competitors not able to use certain corporate's Trade Secret as explained in Article 3 section (2) of Law Number 30 Year 2000 on Trade Secret stating that information is considered secret if those in-formation are only known by certain parties or not known publicly. If it is known by other par-ties, they are no longer considered as Trade Secret. Therefore, the confidentiality of various products must be protected. It is not allowed to be exposed but its legality can still be seen by authorized institutions. There is legal action if other parties use, produce, and sell the secret intentionally.

The protected asset in accordance with Article 3 section (3) of Law Number 30 Year 2000 on Trade Secret is "Information was believed having economic value if its confidentiality can be used to run comercial activities or can economically increase the profit". Law Number 30 Year 2000 on Trade Secret in Articles 3 and 9 explains that the meaning of "running comercial activities" is that information can be useful and profitable if it is used massively and not for limited use. Therefore, the protected aspects in Trade Secret include procedure, sys-tem, process, steps, formula not the product, also the series of activities by using certain pro-cedure, system, process or formula kept by the products either goods or services with the aim to gain the profit.

Trade Secret protection occurs when the agreement is still in progress or has terminated based on contract freedom principle and Law of Trade Secret which does not limit time period of protection. Trade Secret is repetitive; it remains protected to be unknown by other parties. Although Trade Secret protection does not require registration in Directorate General of Intelectual Property, Trade Secret gains legal protection for its previlege. Hence, the existence of agreement between employer and employees which causes the obligation for employees to keep the information of the company is not con- tradicted with valid legislation and it is done by the employers to keep their precious information. ${ }^{21}$

The contract or agreement terminates: first, on its due. Thus, the date of contract termination is set the last day of the valid contract. Then, after the contract ends, the employees do not have any obligation for no longer legal force. second, law determines the time limit of contract. It can relate to Law of Trade Secret in which when the contract is over, the parties involved are still bound for its prolonged protection. Therefore, even if the contract ends, they are still legally related. ${ }^{22}$ Third, the contract is over because what are agreed within the contract are already done. The last, certain condition that is intended is called overmacth. ${ }^{23}$

Legal Consequence of the Implementation of Non-Competition Clause as the Basis of Trade Secret Protection in Indonesia

Observing the legislations applied in Indonesia, the stipulation on Non-Competition Clause has not been regulated. It does not mean no explicit regulation that the clause cannot be implemented. Practically, the clause exists in employment contract between company and employees. Hence, the policy regarding this clause becomes the basis of implementing agreement for both parties, as stated in Article 1338 Burgerlijk Wetboek/Code of Civil law: "All agreements which are legally made can be used as Law for those who make it”. By this clause, employees oblige to fulfill it.

The implementation of a contract relates to the validity of the contract itself. If a contract does not meet the validity requirement, it is possible to be cancelled in law. To implement employment contract, it is necessary to observe the validity of the contract. The employment contract that violates the regulation can be

21 Abdulkadir Muhammad, 2001, Kajian Hukum Ekonomi Hak Kekayaan Intelektual, Bandung: PT Citra Aditya Bhakti, p. 21.

22 Endang Supardi, "Franchise Sebagai Salah Suatu Usaha Bidang Industri”, Jurnal UPI, Vol. 7 No. 2, April 2007, p. 13.

23 Ari, “Perlindungan Hukum dalam Perjanjian Kerja”, Jurnal Rekam, Vol. 10 No. 10, Juni 2015, p. 10. 
deemed illegal, so it brings the consequence for both parties toward the implementation of that employment contract.

One of companies that applies Non-Competition Clause in the employment contract is PT Fast Food Indonesia (KFC Indonesia). The Non-Competition Clause is morally not detailed. The implementation prevent employees from working in another company without company's permission, especially similar companies. The employees have to keep Trade Secret during working there or even if the contract is terminated, they are not allowed to violate rights of ownership from the information and/or materials given to the employees, or any use of information and materials about Intellectual Property of company. Moreover, employees are not allowed to give information about management system and strategy to other parties especially similar companies. Employees are not allowed to open fast food restaurant using any item related to PT Fast Food Indonesia Tbk, such as the materials, products, methods, strategies, production machine, and promoting the products as like KFC.

PT Fast Food Indonesia Tbk obliges to monitor their employees in each KFC throughout Indonesia; the company must make agreement with vendor as supporting colleagues in keeping company's Trade Secret; company has to give right to the employees to stop working or open their own business with condition that they have to deliver detailed reason and keep company's Trade Secret; company obliges to give employees compensation if they experience any loss for its implementation; and company has right to give sanction to the employees who have violated the employment contract in accordance with valid legislation.

Before the employees start working, they are asked to sign a contract containing requirement for keeping company's Trade Secret. If they are proven to breach the agreement such as passing around the information to public concerning method, strategy, or knowledge, it will be imposed admonition sanction, closing their business and paying the compensation, until bringing a lawsuit to the court.
Stipulation on the violation of Trade Secret is regulated in Chapter VII Articles 13, 14, and 15 of Law Number 30 Year 2000 on Trade Secret. Article 13 states:

"Trade Secret violation may occur if someone intentionally reveals the Trade Secret, breaks the contract or written and unwritten obligation to keep Trade Secret."

It means the violation happens if one intentionally circulates the information or breaks the agreement and obligation (default) of the contract that has been made either explicitly or implicitly to keep the Trade Secret.

One is perceived violating Trade Secret if he/she acquires the Trade Secret illegally. The exception of Trade Secret violation regulated in Article 15 of Trade Secret Law is given to the revealation or the use of Trade Secret for some interests such as security and defense, health, and safety of public, also re-engineering action of a product resulted from using Trade Secret for the sake of further development of product. Stipulation on the exception of Trade Secret violation should be equipped with the stipulation which states clearly about Trade Secret revealation in front of court by judge's order. Someone who reveals Trade Secret in front of court considered as exception, so he/she is not deemed violating Trade Secret. ${ }^{24}$

Through general judiciary, employers can file a civil lawsuit first and then if it fails they can file criminal charges. Moreover, all parties can propose court to conduct closed trial. In civil terms, employees may be the subject of claim for conducting default (if they still work at the owner of Trade Secret) or unlawful act. Legal basis to file default is clause of contract on obligation to protect Trade Secret existing in employment contract. That clause can be legal basis in doing prosecution according to Article 1338 of Civil Code which states all valid agreements act as Law for those who make them. Meanwhile for unlawful act, the legal basis is Article 1365 of Civil Code. Prosecution based on default is easier to prove than unlawful act

24 Amalia Rizki, op.cit, p. 188. 
since it is based on employment contract of Trade Secret. Criminally, prosecution can be performed based on Law on Trade Secret and Criminal Code. Prosecution based on Law of Trade Secret uses the legal basis of Artice 13 and Article 17 section (1), which is 2 years imprisonment penalty and/or compensation Rp. 300.000 .000 ,- (three hundreds million rupi-ah) at most. For Trade Secret violation based on Law Number 30 Year 2000 on Trade Secret, it can only conducted if there is complaint from party that gets loss (Article 17 section (2)). Therefore, Trade Secret violation is crime by complaint.

Non-Competition Clause violation is strongly related to Trade Secret violation. If an employee violates Trade Secret either through general judiciary in civil terms, criminal charge, or arbitration, or using alternative of dispute settlement, consequently this clause violation can be applied through civil and criminal remedies.

The effort of overcoming the problem in Non-Competition Clause violation by employees can be executed without court proceedings. Several alternatives of dispute settlement in accordance with explanation of Article 12 of Law of Trade Secret include negotiation, mediation, conciliation, or arbitration. All parties may choose to solve their problem outside the court based on the agreement of those parties. Generally in the agreement, settlement of dispute clause usually has been regulated if there is any dispute between both parties. If it is not, all parties have freedom to choose alternative way to settle the dispute.

\section{Conclusion}

The implementation of Non-Competition Clause as the basis of Trade Secret protection in Indonesia is Statutory Approach based on a legislation since Indonesia adheres to Civil Law legal system. There is a legislation regulating Trade Secret namely Law Number 30 Year 2000 on Trade Secret. Legal consequence from the implementation is in the form of obligations that must be conducted by either employees or company.

\section{Suggestion}

Adhering to statutory approach, Indonesia consequently obliges to implement Non-Competition Clause as the form of trade secret protection. Therefore, separated regulation in employment agreement is required. Besides, the addition of specific clauses in employment agreement regarding the implementation of Non-Competition Clause is important so the employees and the company understand their own rights and obligations.

\section{References}

Anand, Ghansam. "Prinsip Kebebasan Berkontrak dalam Penyusunan Kontrak". Yuridika. Vol. 26 No.2. 26 May 2011. Pp. 91101. DOI: $10.20473 /$ ydk.v26i2.265;

Ari, "Perlindungan Hukum dalam Perjanjian Kerja". Jurnal Rekam. Vol. 10 No. 10. June 2015. Pp. 10-23. DOI: 10.24821/rekam. v0i0;

Bechtold, Stefan, Felix Hoffler. "An Economic Analysis of Trade-Secret Protection in Buyer-Seller Relationships". The Journal of Law, Economics, and Organization. Vol. 27 No. 1. 1 April 2011. Pp.137-144. DOI: $10.1093 /$ jleo/ewp020;

Chen, Youngmin, "Refusal to Deal, Intellectual Property Rights, and Antitrust". The Journal of Law, Economics, and Organization. Vol. 30 No.3. 1 August 2014. Pp. 533-557. DOI: 10.1093/jleo/ewt004;

Friedman, David D, William M. Landes, Richard A. Posner. "Some Economic of Trade Secret Law". The Journal of Economic Perspectives. Vol. 5 No. 1. Winter 1991. Pp. 61-72. DOI: 10.1257/jep.5.1.61;

Garmaise, Mark. "Ties That Truly Blind: NonCompetition Agreements, Executive Compensation, and Firm Investment". Journal of Law, Economics, and Organization. Vol. 27. 2011. Pp. 376-425. DOI: 10.2307/ 41261726;

Marx, Matt. "The Firm Strikes back: Non-Compete Agreements and the Mobility of Technical Professionals". American Sociological Review. Vol. 76 No. 5. August 2011. Pp. 698-715. DOI: 10.1177/0003122 411414822;

Mayer, Robert N. "Protectionism, Intellectual Property, and Consumer Protection". Journal Consumer Protection. Vol. 21 No. 
2. June 1998.Pp. 196-215. DOI: 10.1023/ A:1006816018142;

Muhammad, Abdulkadir. 2001. Kajian Hukum Ekonomi Hak Kekayaan Intelektual. Bandung: PT Citra Aditya Bhakti;

Purhagen, Kai. "Principles of European Private or Civil Law?". European Law Journal. Vol. 18 No. 16. November 2012. Pp. 844867. DOI: 10.1111/eulj.12006;

Ramli, M Ahmad. 2000. H.A.K.I: Teori Dasar Perlindungan Rahasia Dagang. Bandung: Mandar Maju;

Rizki, Amalia. "Non Competition Clause Dalam Perjanjian Kerja". Yuridika. Vol. 26 No. 2. May 2011. Pp.117-128. DOI: 10.20473/ ydk.v26i2.266;

Schultz, Mark F. "Approaches to Protection of Undisclosed Information (Trade Secrets)".
OECD Trade Policy. Vol. 16 No. 1. April 2014. Pp. 11-23. DOI: $10.1787 / 5 j z 9 z 43 w 0$ jnw-en;

Sudjana and Elisantris Gultom. 2016. Rahasia Dagang dalam Perspektif Perlindungan Konsumen. Bandung : CV Keni Media;

Supardi, Endang. "Franchise Sebagai Salah Suatu Usaha Bidang Industri", Jurnal UPI, Vol. 7 No. 2. April 2007. Pp. 13-22. DOI: 10.17509/gea.v7i2.1718;

Tsotsorin, Maxim V. "Practical Considerations in Trade Secret Licensing". Intellectual Property Patent Law Journal. Vol. 10 No. 3. October 2012. Pp. 202-218. DOI: 10.21 39/ssrn. 233. 